\title{
Implementation of Contract Hybrid Concept in Multi Services Products (Aplication of the Warranty Bank Products/Kafalah in Syariah Banks)
}

\author{
Muhammad Firmansyah ${ }^{1}$ \\ 1 Sharia Economic Law, Faculty of Sharia and Law \\ Sunan Gunung Djati State Islamic University Bandung, Indonesia \\ Email: firmaneott91@gmail.com
}

\begin{abstract}
:
Product of multi services in sharia banks presented in order to meet the needs of society as well as the development of the era transactions that course in accordance with Islamic principles, then the ownership in the syariah products including multi product in Islamic banking services using the concept of multi akad therein. This is done so that innovation in Islamic banking products had been developed so that it can be chosen by the public in conducting business transactions. Likewise, the multi-service bank guarantee products in Islamic banking, is a multi product contract, where there is more than one contract. Bank guarantees in Islamic banking is generally called kafalah product because this product is Kafalah main contract, followed by ljarah contract, wadiah, and qardh. This paper examines the concept of multi-contract/contract executed hybrid shariah banking at bank product warranty/kafalah
\end{abstract}

Keywords: Warranty Bank, Kafalah, Sharia, Islamic Banking

\section{A. INTRODUCTION}

Generally, the products offered Islamic banking is divided into three parts, namely, product distribution of funds (financing), products fund (funding), and the product of service (service). The financial services sector in the economy would no doubt, in today's modern world of economic life can not be separated from the presence and the important role the financial services sector in general and banking in particular, through the financial services sector this is the fund or the investment potential that exist in society channeled into productive activities, so that economic growth can be realized (Karim, 2001: 97).

The majority of Islamic banking products, is actually a blend of conventional banking practices with the basic principles of Islamic economic transactions. Islamic banking products-was almost entirely a product of which there are several contracts in one product (hybrid contract), this is done for financial transactions of sharia could adjust to the needs and developments in the community, of course, with nothing out of the rules, principles -asas, as well as the values of islamic economics. Thus, Islamic banking products become very broad and more comprehensive than conventional products, for example in product and services that are increasingly growing and more and more products are being 
offered to the public, it indicates that the product and services the bank sharia is very diverse, and became a multi services, where the product services did not only focus on the services sector alone.

Surely many in the Islamic banking products not only to meet the market needs, but also adapted to the values of sharia, not the origin of adopting the conventional banking products without any prior adjustments to the values of Islamic economics. Although in practice there are some products that are technically almost not different from the conventional banking products one banking products shari'ah 'ah is kafalah services which in conventional banking product called a bank guarantee. Although technically almost not much different from the bank guarantee in conventional banking, but the bank guarantee on the products of Islamic banking is commonly called kafalah have the different characteristics.

\section{B. METHODS}

This Paper used the literature study by searching variety of references related to the topic about Implementation of Contract Hybrid Concept in Multi Services Products. This paper is a conceptual explanation of sharia compliance substantively that produced legal based of point of view in one of sharia banking product.

\section{RESULTS AND DISCUSSIONS}

\section{Definition of Warranty Bank}

In the business world, capital is absolutely necessary for the various activities. Capital in the form of money can be given in the form of cash, or also through a guarantee in the form of securities. Sometimes employers prefer to use securities, because to obtain cash is not easy. Securities can be used as collateral to finance a business or project. This guarantee is usually provided by a bank with a note beforehand that customers provide a guarantee where the amount of collateral opponent opponents usually exceeds the value of the project as collateral. This is done to ensure customers when will work on the project. Guarantees issued by the client a sum of money so that the giver will feel confident the project will not be harmed if the project is run by the businessman. This guarantee is known as Warranty Bank (Kasmir, 2004: 194).

So, we can say that the basic understanding of a warranty bank is a guarantee of the payments made by the bank to a party, both individuals and companies or entities in the form of letters of guarantee (Kasmir, 2004: 195) Giving this assurance the intention is that the bank guarantee would meet the (pay) the obligations of the parties pledged to the person receiving the pledged collateral if the later did not fulfill obligations to the other party in accordance with the agreement or breach.

Warranty Bank is a letter of guarantee issued by banks to guarantee the third party at the request of customers in connection with the transaction or contract they had agreed beforehand. It includes, for example: tender guarantees, performance bonds, advance payment guarantees and performance bonds with a minimum deposit of 10\% of the desired guarantee customers (Hakim, 2011: 280).

Warranty Bank is a written guarantee from the bank provided to its customers (guaranteed) to fulfill an obligation, and if the party is assured in the future was not able to meet obligations to third parties in 
accordance with the agreement (default), then the bank as the guarantor may take action to collection to the insured (beneficiary) (Judisseno, 2002: 173). In other words, the Warranty Bank is a letter of guarantee issued by banks to guarantee third parties upon request of the customer. In the event of default of the customer to a third party, by virtue of a bank guarantee that third parties can file a claim with the guarantee issuing bank (Janwari, 2015: 132).

Type a bank guarantee in banking can be a bid bond, performance bond, advance payment bond, retention bond / maintenance bond, custom bond and bond shipping. The six types of bank guarantee is a guarantee issued by a bank at the request of customers for the benefit of a third party as the owner of the project implementing partners customers, but with a different designation, among others, as follows (Janwari, 2015: 281):

a. Bid-linked bonds initial requirements set by the project owner to the contractor who will participate in the tender.

b. Performance bonds related to concerns the project owner against the contractor if the breach of contract work and complete the project as an employment contract.

c. Advance payment bonds, related to prepayment or payment terms by the project owner to the contractor.

d. Retention bond / maintenance bond, associated with customer responsibility for the maintenance of the works until the time limit under the contract.

e. Custom bond, related to the suspension of duties on imported goods for which a suspension of payment.

f. Shipping bond, related to the expenditure of imported goods from the port before the arrival of the original import documents from a bank which negotiates.

Warranty Bank service coverage is full cover, meaning that customers cover the entire bank guarantee and service facilities that are financing or credit indirectly. Warranty Banks for products with full service cover, the authority granted by the official verdict financing breakers in the branch office. While the bank guarantee with ensuite facilities, authority decision must be sought prior permission to breakers official financing regional level or boss of official financing breaker at the branch in question.

In Islamic banking, Warranty Bank practiced using Kafalah contract. Warranty Bank in Islamic banking is done by the bank as guarantor (kafil) issue a bond to the project owner or business at the request of customers in accordance with the transaction that has been agreed between the bank, the customer, and the project owner. However, in case things are not desirable as risks beyond intent or negligence by a letter of guarantee issued by the bank (kafil) then the third party that the project owner can mengajukam claims to the issuer bank guarantee.

Kafalah none other borgtoch agreement or guarantee, either in the form of personal guarantee or corporate guarantee, known in conventional banks. Technically in kafalah of Islamic banking is a service where the customer guarantee bank acting as guarantor (kafil) while customers a guaranteed party (SE BI No. 10/14/DPbS, 2008). Islamic principles as a bank guarantee services, namely guaranteeing the payment of an obligation of payment. Banks may require the customer to put some funds for this facility as collateral. The fund can bank on meperlakukannya with wadiah principles and in this case the bank to get a reward for services (Hakim, 2011: 280). 
From customers, banks earn rewards in the form of a fee (ujrah) in a nominal fixed amount agreed upon in the beginning of the transaction. In fact, he may ask for collateral in the form of cash collateral or other guarantees on the value of the guarantee. However, the bank tertuntut to provide bailout funds as financing based on qardh which should be completed by the customer, if the customer can not meet its obligations to third parties. All agreements on the basis of a guarantee transactions kafalah between the parties and the customer is manifested in the form of a written agreement that has binding legal effect (Hakim, 2011: 282).

Meanwhile, according to Adiwarman Karim, Bank Guarantees in Islamic banking can be given in order to guarantee payment of an obligation to pay. Banks may require the customer to put some funds for these facilities as Rahn. Bank may also receive funds in accordance with the principle of wadi'ah. For these services, the bank receives a replacement fees for services rendered (Karim, 2007: 107).

Kafalah (warranty bank) as banking services is a written agreement that the contents of banks agree to bind themselves to the insured in order to meet the obligations guaranteed within a certain period of time and with certain requirements in the form of payment of certain amount of money if it is assured in the future did not meet obligations to the insured

\section{The Legal Basis of Warranty}

Bank Guarantee contained in several regulations including the Law number 13 of 1968 About the Central Bank Chapter XI Article 41 paragraph 6 states that the bank provides bank guarantees with sufficient dependents. The same thing is mentioned in Law No. 14 of 1967 On the Principles of Banking Chapter V Article 23 paragraph 7. However, both this Act does not apply anymore and has been replaced by Act No. 7 of 1992 on Principles of Banking later is amended by adding at the Law number 10 of 1998 on Banking and Law No. 23 of 1999 concerning Bank Indonesia.

But in all three of this law did not explain in detail about the bank guarantee. This Act only mention of guarantee, and even then, only in passing. A detailed explanation regarding these bank guarantees described in the regulations issued by Bank Indonesia, the Bank Indonesia Board of Directors Decree No. 11/110 / Kep. / Dir on Issuance of Guarantees by Banks and Warranties By Giving Non-Bank Financial Institutions. According to this Decree, a guarantee not only by banks but also by non-bank financial institutions, based on Article 1 of the decree can know some things about the guarantee in question include (Bank Indonesia, 1979):

a. Warranty is shaped slips issued by the bank or non-bank financial institution that gave rise to the obligation to pay to the party receiving the collateral if guaranteed in default or breach of contract.

b. This is done by signing collateral securities where those securities give rise to liability to pay for a bank or non-bank financial institutions guaranteed if the party did breach.

c. This guarantee is a guarantee that occurs because of a conditional agreement that can lead to financial obligations to the bank or non-bank financial institutions

In Article 2, paragraph 1 (Bank Indonesia, 1979). This decision letter states that the guarantee referred to in article 1, paragraph 1 issued by the bank is a bank guarantee. Then the Bank Indonesia Board of Directors Decree was revoked later improved and was replaced by the Decree of Directors of Bank 
Indonesia Number 23/88 / Kep / Dir. March 18, 1991 on the Granting Guarantee by the Bank. In this decision letter stated notion that the bank guarantee referred to in article 1, paragraph 3a which sounds are (Bank Indonesia, 1991):

"Warranty is a guarantee in the form of paper issued by the bank which resulted in the obligation to pay to the party receiving the warranty if the guaranteed party breach of contract (default). The conclusion that can be drawn from articles in the decree is that the definition of a bank guarantee is a guarantee in the form of paper issued by the bank which resulted in the obligation to pay to the insured if it is assured in default".

In detail, the provisions of kafalah in Islamic banking operations stipulated in Circular Letter No. 10/14 /DPbS year 2008 regarding the implementation of Islamic principles in the activities of fund raising and distribution of funds and Islamic bank services. The provisions in the SE BI more associated with the bank as kafil compared with provisions relating to the customer and the guarantor objects. SE BI puts the bank as guarantor for penenuhan clients' obligations to third parties, and he was obliged to explain to the customer characteristics of the service on the basis of a guarantee kafalah and the rights and obligations of the customer. Other provisions related to the bank is the obligation to conduct an analysis of the service plan of a guarantee to customers that include personal aspects such as character and business aspects such as the capacity of business, financial and business prospects.

In Law No. 21 of 2008 concerning Islamic Banking, kafalah as covenants used in the products mentioned in Article 19 paragraph 1 and 2-point i. (UU RI No. 21, 2008). Kafalah of this verse is one of the alternatives in addition to ljara, Musharaka, mudaraba, murabaha, and hawalah to the business activities of Bank Syariah which includes buying, selling, and guarantees on own risk securities a third party issued on the basis of real transactions based on Islamic principles. Article 19 paragraph 1 letter I intended for BUS and article 19 paragraph 2 letter I intended for UUS. Real transactions in the second paragraph above is a transaction based on the intangible asset. The kafalah according to Law No. 21 is "the provision of a guarantee given Akad one party to another party where the guarantor (kafil) is responsible for repayment of the debt are the rights of the insured (makful)".

As for the activities of the bank guarantee of the MUI fatwa in Islamic banks arranged in a fatwa NO: 11 / DSN-MUI / IV / 2000 on Kafalah. In the fatwa was mentioned also the cornerstone of the Quran and hadith. Following the decision of the fatwa:

Firstly, the General Conditions Kafalah:

a) Qabul consent statement and must be declared by the parties to demonstrate their will to enter into a contract (contract).

b) In kafalah contract, the surety may receive remuneration (fees) to the extent not burdensome.

c) Kafalah exchange is binding and can not be canceled unilaterally

Second, Pillars and Conditions Kafalah:

a) Party Guarantor (Kafiil):

i) Baligh (adults) and sensible. 
ii) full Entitled to take legal action in the affairs of his property and willingly (the pleasure) with the kafalah dependents.

b) People who owe the party (Ashiil, Makfuul 'anhu):

i) Able to submit their dependents (receivable) to the guarantor.

ii) Known by the guarantor.

c) Party People indebted (Makfuul Lahu):

i) Given their credentials.

ii) Can be present at the time the contract or authorize.

iii) sensible.

d) Object Assurance (Makful bihi):

i) It is borne by the party / person who owe, whether it be money, objects, as well as jobs.

ii) Can be implemented by the guarantor.

iii) Must be a binding receivables (prevalent), which is impossible to remove except having paid or waived.

iv) It should be obvious value, quantity and specifications.

v) There is contradictory to shari'a (forbidden).

Third, if one party does not fulfill its obligations or if there is a dispute between the parties, the settlement by the Arbitration Board Shariah after no agreement was reached by consensus.

The fatwa was determined that kafalah services performed by each procedure Islamic bank that provides, with reference to the general provisions of the bank guarantee has been established by Bank Indonesia and the kafalah pillars that have been set by the National Islamic Council of Indonesian Ulama Council. The provision of this fatwa is based on the background that is in running the business, one often requires a guarantee from the other party through kafalah contract. Kafalah Award is given with the intent to meet the needs of one's business. Then the National Sharia Council deems it necessary to set a fatwa on kafalah as a guideline for Islamic Financial Institutions.

For kafalah issued by Islamic banks in Indonesia, should be subject to the provisions contained in KUHP, ie Book III Chapter XVII of Article 1820 to Article 1850 (Widjanarto, 2003: 96). These Articles regulate the issue of coverage, good nature in general, consequences that arise for both parties and the abolishment of this agreement. In this section, which will provide protection for the parties to make that bank and guaranteed party. Because kafalah is included docking accesoir, then there is a relevant third party in it, namely the insured. The existence of these third parties are protected by Articles 1314 and 1340 of KUHP. ${ }^{1}$ In addition to be subject to the provisions of the Civil Code, granting kafalah should also be subject to the Law No. 7 of 1992 on Banking, Law No. 10 Year 1998 on Banking, Decree of Directors of Bank Indonesia regarding the provision of a bank guarantee and Bank Indonesia Circular Letter regarding the provision of warranty bank.

\footnotetext{
1 1314: Suatu perjanjian dibuat dengan cuma-cuma atau dengan atas beban. Suatu perjanjian cuma-cuma adalah suatu perjanjian bahwa pihak yang satu akan memberikan suatu keuntungan kepada pihak yang lain tanpa menerima imbalan. Suatu perjanjian memberatkan adalah suatu perjanjian yang mewajibkan tiap pihak untuk memberikan sesuatu, melakukan sesuatu, atau tidak melakukan sesuatu.

1340: Persetujuan hanya berlaku antara pihak-pihak yang membuatnya. Persetujuan tidak dapat merugikan pihak ketiga; persetujuan tidak dapat memberi keuntungan kepada pihak ketiga selain dalam hal yang ditentukan dalam pasal 1317. (KUHPerd. 1178, 1523, 1815, 1818, 1857; F. 152.)
} 


\section{Implementation of Warranty Bank in Islamic Financial Institutions}

In practice, the LKS act as guarantor (kafil) where the LKS will bear guarantees payment to the recipient (makful lahu) if the client side project (makful anhu) are in default. As for the costs incurred and to be paid by the customer for the issuance of a performance bond consists of administrative costs which the determination of the amount determined by the overhead costs are costs incurred on the issuance of a performance bond as the cost of ATK (stationery), income fee base income and policy committee. The results from the accumulation of the three is in the form of a nominal fee. In addition to administrative costs, customers also charged stamp duty.

"Example: On October 18, 2015 PT. Cyclone Squares submit bank guarantee facilities to LKS kafalah performance bond to ensure the procurement of fuel coal for PT. Earth's core with a project value of Rp 400,000,000, - (four hundred million). After receiving the submission, then the LKS perform an analysis of the proposal, the better analysis is based on an analysis of $5 \mathrm{C}$ and a contract between PT. Typhoon Squares with PT. Earth's core. Once known the results of the analysis and the filing stated can be granted, then on December 3, 2015 the finance committee gives approval letter of bank guarantee of the performance bond with the statement therein that the Bank guarantees financing

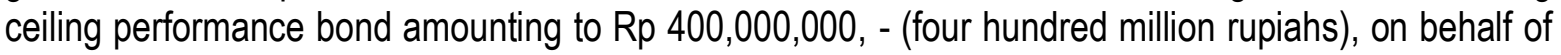
PT. Cyclone Squares, the usefulness of the performance bond is to ensure the implementation of the fuel providing coal to PT. The core is the decree of appointment, term of 5 months, an administration fee of Rp 50,000, - per month and ujrah Rp 250.000, - during the berlakunnya a performance bond is 5 months, the cost of stamp duty amounting to Rp 6,000, - and guarantee the deposits in the name of PT, Typhoon Squares blocked Rp 400,000,000, - (four hundred million rupiah)"

After completion of kafalah, settlement akadnya can be done in two ways. First, the settlement without any claims, second, with claims settlement. Without claims settlement if the parties indebted (makfuul lahu) does not claim to LKS, in other words the Makfuul anhu successfully carry out its obligations, then if such party LKS withdraw the bank guarantee letter. Completion of the claim if the parties indebted (makfuul lahu) filed a claim to LKS, in other words the parties are guaranteed by LKS (makfuul anhu) could not make the obligation (default) to the parties indebted (makfuul lahu). If that happens, the BLM will pay to the parties indebted (makfuul lahu) and cash payments are taken as loan financing qardh for parties guaranteed by LKS (makfuul anhu) and the guaranteed party must repay the financing qardh them if they can not pay off the financing of the party will conduct the liquidation of collateral LKS.

\section{Kafalah Contract}

Kafalah within the meaning of language is to convey the same al-daman word that means combining

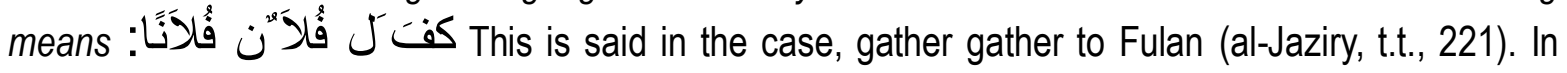
Arabic kafalah is the definition of the word kafala (كفل) means bear, yakfulu (يكفل), kuflan (كفل) guarantee, takaaful (تكاقل) each bear, yatakaafulu (تبتكافل), takaafulan (تكافلا) insurer (Munawir, 2000: 1220). Al-Kafalah itself is called by several names, including: damanah (bail), hamalah (expense), and za'amah (dependents), initially kafalah are guidelines with daman word which means the guarantee, but the subsequent development of the meaning of kafalah shift. Kafalah identical with 
al-Wahdi kafalah (personal guarantee / collateral self), while damanah shaped identical to guarantee absolutely.

If it is associated with the parties determined / liability for the kafalah (as isim fa'il), then kafalah has another name even more, namely: Damin (guarantor), Kafil (the insurer), pregnancy (the burden), Za'im (insurer), Cain (receiver), and Sabir (those who hold). More specifically each of these names turned out to be linked to the object of his kafalah. Kafalah Dhamin for large-scale objects, Kafil for objects such as people, while Sabir for all objects kafalah (al-Zuhayli, 1997: 78). While the terminology, concepts kafalah gave rise to many interpretations among scholars of figh. Hanafi Ulama explain the definition Dhaman or kafalah there are two opinions, namely:

a. Kafalah is collecting an amenability to other dependents in terms of charge or prosecute themselves, debts or objects.

b. Kafalah is collecting an amenability to other dependents in principal.

Kafalah as a service guarantee is one form of engagement in Islam. as a form of engagement in Islam, the conditions of validity of an engagement in the form of kafalah should be based on the provisions of Islam. In the opinion of Sayyid Sabiq book Commitments Islamic law, states that the requirement of the validity of an engagement are (Pasaribu dan Lubis, 1993: 2):

a. The follow Sharia law are signed; It means that the agreement held by the parties was not the act that is unlawful or contrary to sharia law, for an agreement contrary to the provisions of sharia law is not valid. So naturally there is no obligation of each party to keep or enforce the agreement. In other words, all forms of agreements that are contrary to sharia law itself null and void.

b. Must equal the pleasure and there is a choice; That is the agreement of the parties shall be held based on the agreement of both parties, that each party would be willing to fill the pleasure or the agreement or in other words the content of the agreement is the will of the parties. In this case there should be no coercion from one party to the other party. If there is an element of coercion agreement, the agreement held by itself has no legal force.

c. It should be clear and understandable; That is what is at perjanjikan by the parties must be candid about what the content of the agreement, so it does not result in terjadinnya misunderstanding among the parties about what they perjanjikan later. Thus, at the time the agreement was made then each party shall have the same interpretation of what they perjanjikan both the content and the consequences caused by the agreement.

The terms of the engagement over the Islamic Republic is an absolute requirement that must be met by any kind of engagement conducted in public life including the engagement in terms of kafalah. More precisely referred to as the general condition of the engagement kafalah. Specifically, kafalah has its own absolute terms more appropriate if called as the special terms of the engagement kafalah. Said to be a specific requirement for the terms of the content containing technical matters concerning kafalah. 


\section{Hybrid Contract on Warranty Bank in Islamic Financial Institutions}

Services Bank Guarantees / Kafalah in LKS as well as other products such as financing is a product in which there are the incorporation of some contract or commonly known as a multi-product agreement / hybrid contract. Although the bank guarantee in LKS often named by kafalah product, but if viewed from the transaction, the transaction agreement kafalah not only use, but also a top ljara contract fee received by LKS. Fee or received comes from ujrah Islamic banks on the guarantee provided by the customer. Collateral in the form of assets of clients or savings, deposit or current account kept by the bank and is considered as a deposit with the contract wadiah and from deposit bank received ujrah, and also qardh granted by BLM to settle clients' obligations to makfuul lahu that must be paid by the client to LKS, if the customer can not carry out its obligations to the makfuul lahu.

Regarding guarantees in bank guarantees, bank financing in each application has the provision submitted to each of its customers. With worries that the bank assign to each customer get Kafalah services (bank guarantee) give a guarantee to the Bank to cover if there is something undesirable. Collateral in the form of savings, deposit or current account or securities which at times can be taken by the bank in case of failure in implementing the project. Assurance function to reduce the risks to be faced by the bank for services provided to the customer as well as any condition or analysis as possible, the risk of loss either intentional or accidental can happen. Provision of services without a guarantee very dangerous position given the bank if the customer is unable to perform its obligations it will be difficult to cover the losses.

Kafalah developed at this time a lot of that is based on merit kafil wage because it is difficult to find people who will want to voluntarily even become guarantor for someone else. Although basically Kafalah should be voluntary and in the framework of mutual help, but this is done in order to eliminate the difficulties and get a more important benefit. Making wages in kafalah allowed for not burdensome for the debtor. The objective of the kafalah namely that the life arises a sense of helping each other to relieve the burden of others. If the wages of the debtor objected make the benefits of kafalah that is helping in the good to be lost, and if this happens then kafalah world only wants reward only.

Wahbah al-Zuhayli stated that kafalah is developing now many are constituted with the reward for alkafil services, due to the difficulties to find people who want to volunteer to be the guarantor of others. According to him, the agreement may be enforced wage kafalah or services, provided that they do not serve as the kafalah of land to cultivate profits. Allowing for wage on kafalah is based solely on the state of emergency and urged for makful "anh, so if voting was not allowed wage will be more difficult for him. This law is analogous to Wahbah Zuhayli like bolehnya take wage law in the teaching of the Qur "an Islamic science or other (Dahlan, n.d.: 849).

According to Mustafa Abdullah al-Hamsyari, citing the opinion of Imam Shafi 'i the judge giving the money to the person who is assigned to complain about a problem or offer something to the king can not be considered kickbacks (risywah), but is considered a wage, and the law should be as reward tired or travel expenses. Other contemporary scholars, Abdul Sa "i al-Mirri, saying that a guarantor shall be rewarded according to his job as a guarantor. This opinion enters it opened up opportunities in consideration the emotion of risk borne by the guarantor in calculating wages. So, when wages had become commonplace and become a habit, then the stretcher is allowed and even required when it can not be done without their wages. This is in accordance with Qaeda fighiyyah (Usman, 2002: 202): 


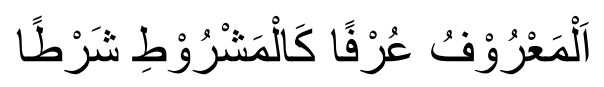

"Something prevailing custom is considered as a condition".

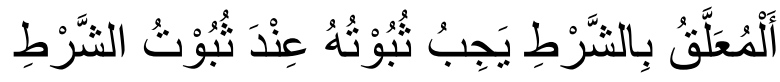

"Something that is associated/suspended on a condition when the condition exists then it must be"

\section{CONLUSION}

Warranty Bank is one part of the many products multi services offered Islamic banking. Warranty Bank in Islamic banking is generally referred to as kafalah product is a multi product contract, in which there are more than one contract. It poses kafalah contract, wadiah, and ljara, and qardh if the customer in default to third parties. With Akad kafalah, bank guarantees to third parties that the client is able to carry out a given project third party, if the client defaults, the bank will guarantee it. Islamic banks get kafalah ujrah of services provided, and also on a guarantee provided by a customer in the form of assets, savings, deposits, or checking accounts secured bank customers during the warranty lasts. This guarantee is required for customers to get a bank guarantee from Islamic banks and to guarantee if the customer makes default to a third party. The qardh do if the customer in default to a third party, so the bank gave qardh to customers, with qardh the customer to meet its obligations to third parties and must replace the Islamic bank, if the customer can not pay qardh, then the collateral will be liquidated by Islamic banks.

Warranty Bank, in addition to profit, done in order to provide facilities to facilitate customer transactions, to holders of assurance (third party) guarantee bank beneficial to obtain assurance that third parties will not suffer losses because losses will be borne by the bank that issued the guarantee, so that will foster mutual trust and secure between the insurer and who receive a guarantee. 


\section{References}

al-Jaziry, Abdurrahman. (n.d.). Al-Figh „ala al-Mazahibul Arba“"ah, Jilid III, Beirut Libanon, Dar al-Fikr. al-Zuhayli, Wahbah. (1997). Al-Fiqh al-Islam wa Adillatuh, Juz. V, Damaskus: Dar Al Fikr.

Dahlan, Abdul Aziz. (n.d.). Ensiklopedi Hukum Islam, Jakarta: Ikhtiar Baru Van Hoeve

Fatwa DSN MUI NO: 11/DSN-MUI/IV/2000

Hakim, Atang Abd. (2001). Figh Perbankan Syariah, Bandung: PT. Refika Aditama.

Janwari, Yadi. (2015). Fikih Lembaga Keuangan Syariah, Bandung: Remaja Rosdakaya.

Judisseno, Rimsky K. (2002). Sistem Moneter dan Perbankan di Indonesia Jakarta: Gramedia Pustaka Utama.

Karim, Adiwarman A. (2001). Bank Islam Analisis Fiqih dan Keuangan, Jakarta: Gema Insani.

Karim, Adiwarman A. (2004). Ekonomi Islam Suatu Kajian Kontemporer, Jakarta: PT. Raja Grafindo Persada.

Kasmir. (2004). Dasar-Dasar Perbankan, Jakarta: PT Raja Grafindo Persada.

Kitab Undang-undang Hukum Perdata

Munawir, Ahmad Warson. (2000). Al-Munawir Kamus Arab-Indonesia, Surabaya: Pustaka Progresif.

Pasaribu, Chairuman dan Lubis, Suhrawardi K. (1993). Hukum Perjanjian Dalam Islam, Jakarta: Sinar Grafika.

SE BI No. 10/14/DPbS Tahun 2008, Bagian IV.1.1.A

Undang-undang Perbankan Syariah (UU RI No. 21 Tahun 2008)

Usman, Muchlis. (2002). Kaidah-Kaidah Ushuliyah \& Fiqhiyah, Jakarta: PT. Raja Grafindo Persada.

Widjanarto. (2003). Hukum dan Ketentuan Perbankan di Indonesia, Ed. IV Jakarta: Pustaka Utama Grafiti. 
Implementation of Contract Hybrid Concept in Multi Services Products

(Aplication of the Warranty Bank Products/Kafalah in Syariah Banks) 